\title{
$+2$ \\ CHAPTER VII. PRIVATE INDUSTRY
}

The private sector has played the major role in the development of geothermal energy. The largest geothermal project in the world, The Geysers, was initiated and developed to its current status by the private sector. The government, primarily since 1970, with the passage of the Geothermal steam Act, has attempted to accelerate the development of the geothermal industry by providing access to resources on public lands (leasing) and by removing technical, economic, and institutional barriers. However, the development of a significant geothermal industry in this country and the production and use of significant amounts of geothermal energy rests with the private sector.

Initially the geothermal industry was organized around the exploration, development, and use of geothermal energy for the production of electricity. Recently the industry has changed its focus as difect use and development of low-to moderate-temperature resources have become more important.

The industry is composed of four very diverse groups: major energy companies, companies organized for the express purpose of developing geothermal energy (geothermal companies), engineering companies, and users. A more detailed breakdown on types of companies involved is presented in Table VII.1.

Energy Companies. Most of the energy companies are involved in the development of geothermal energy, in one form or another, is an extension of their general mission as energy suppliers. The major objective of the energy companies is the production of steam for electrical power. Currently, they show little interest in direct heat applications, primarily because of the small size of most of these activities. Energy companies have been among the most active in acquiring resources on Federal land by competitive bidding. The major energy companies have also been active in exploring and developing the resource. They have not been very involved in energy conversion (power plants) or energy use.

Geothermal Companies. The companies have usually been formed for the express purpose of developing geothermal energy. In general; they are smal1--but some have developed affiliations with very large energy companies. Their current role ranges from exploration support to the production of steam and ultimately to the production of electricity. They often promote joint action between energy companies as operators and utilities as users.

Engineering Companies. These companies are generally small, special purpose engineering companies that pioneer certain plant design concepts or components thereof, but are often large architectural and engineering firms that design and build geothermal plants in the same manner as other energy generating plants. These companies see themselves as the techifical bridge between the developer/operator and the final user of the geothermal energy resource. Although they prefer to limit their role to design and construction, they often find themselves marketing geothermal energy to 


\section{DISCLAIMER}

This report was prepared as an account of work sponsored by an agency of the United States Government. Neither the United States Government nor any agency Thereof, nor any of their employees, makes any warranty, express or implied, or assumes any legal liability or responsibility for the accuracy, completeness, or usefulness of any information, apparatus, product, or process disclosed, or represents that its use would not infringe privately owned rights. Reference herein to any specific commercial product, process, or service by trade name, trademark, manufacturer, or otherwise does not necessarily constitute or imply its endorsement, recommendation, or favoring by the United States Government or any agency thereof. The views and opinions of authors expressed herein do not necessarily state or reflect those of the United States Government or any agency thereof. 


\section{DISCLAIMER}

Portions of this document may be illegible in electronic image products. Images are produced from the best available original document. 
Table VII. 1

TYPES OF COMPANIES INVOLVED WITH GEOTHERMAL INDUSTRY

Large Energy Compantes

Small Energy Companies

Geothermal Compantes

Engineering Companies

Utility Companies

Direct Heat Users

200

Municipalities

Trade Associations

Drilling Companies

5

Financial Institutions

5

Promoters/Developers of 10

Direct Heat Applications 
the user (most frequently utilities) and even underwriting the project risk.

Users. There are two main groups of users: electricity producers and nonelectric users. For electricity, the principal firms involved are a small group of utilities in the western states and, to a lesser extent, some companies, known as geothermal companies, are specially organized for the development of geothermal energy. The latter acquire leases, undertake exploratory activities, and develop the geothermal resources and, in some cases, produce electricity and sell it to utilities for distribution. other electric users include municipalities that intend to develop geothermal for public use and some large industrial users of electricity that own or lease land containing geothermal resources and are evaluating those resources as possible alternative means for generating electricity to meet their needs.

The principal nonelectric users are firms wanting to obtain access to geothermal energy, small resource owners seeking ways to develop or sell the resource, and engineering companies or companies formed as general promoters/developers to put together complete development packages.

Some owners or leaseholders of land containing geothermal resources have sufficient capital and incentive to explore the areas of geothermal potential themselves. This exploratory effort is often the first phase of an overall development program by the owner; at other times, exploration is undertaken to determine the resource's worth for later sale or leasing to developers.

Owners lacking the resources for exploration invite developers to join them in joint ventures, sell their holdings to the developers in direct sales, or maintain their holdings as future investments.

Other than the individual development of small, private holdings, most direct heat applications have resulted from the efforts of intermediaries or general promoters. In some cases, the promoters are engineering companies that have undertaken management of the resources' development programs and the engineering of their applications; in other cases, the promoters have taken their efforts a step further and included in their roles as promoters the securing of venture capital as we11. In addition, new companies have been formed for the express purpose of developing overall programs for the resource owners; and these companies will develop complete financial packages--including the securing of venture capital--as part of the program's integration.

During the past year, striking advances have been made toward the application of hydrothermal resources. One firm, Magma Energy, has completed the construction of a 10 MWe plant in Southern California. This plant, which was in operation early in 1980 , is the first U.S. plant to generate electricity from a hot water resource, and the first geothermal plant in the world of any substantial size to utilize a binary process. Two other 10 MWe plants will be completed in California in 1980. The development of The Geysers has grown to 663 MWe and may reach 1,000 MWe in 1981. 
Union Oil, in a joint activity with Southern California Edison, and Magma with San Diego Gas and Electric, have announced intentions to proceed with two 50 MWe power plants at Niland, California. Chevron and Southern California Edison plan a plant at Heber; California's Department of Water Resources intends to build a hybrid geothermal/wood-waste plant at Honey Lake; and Sierra Pacific is considering plans to build a power plant in northern Nevada. These, their expansions, and other planned projects will bring the expected hydrothermal power on-line (exclusive of The Geysers) to over 350 megawatts by the end of 1982 and 650 megawatts by 1984. The Department of Energy is involved in funding about half of these plants. California is projecting 1,100 megawatts from the Imperial Valley alone by 1986, which, together with a total of 1,900 megawatts planned for The Geysers, will total 3,000 megawatts. Thus, prospects appear favorable for the achievement of a 1985 goal of 3-4 GW of electric generating capacity from geothermal resources.

Geothermal Field Developers

The period from 1975 through 1978 has shown essentially no growth in the rate of geothermal drilling (Table VII.2). There has been very little drilling in areas outside of proven reservoirs where economic feasibility has already been demonstrated to industry (Table VII.2). California's Imperial Valley and The Geysers have accounted for 65-75 percent of all the geothermal drilling in the western United States. No more than 19 major wells were drilled outside of The Geysers or the Imperial Valley in any year through 1978 .

Early evidence suggests that the rate of geothermal drilling increased somewhat in 1979. At least 80 and perhaps upward of 100 wells were spudded. This may reflect a significant impact of the improved financial incentives for geothermal development provided in the 1978 National Energy Act.

The Insurance Company of North America announced in September 1979 that it is prepared to issue reservoir insurance. The policy would cover both the field developer and user, during both development and operating periods. This policy is expected to boost the interest of private developers in assessment, drilling, and development. 
Table VII. 2

GEOTHERMAL DRILLING ACTIVITIES

\begin{tabular}{lccccc} 
CLASSIFICATION & 1975 & 1976 & 1977 & 1978 & 1979 \\
\hline PRODUCIBLE & 37 & 39 & 25 & 30 & 30 \\
SUSPENDED & 2 & 8 & 17 & 15 & 6 \\
ABANDONED & 7 & 5 & 5 & 4 & 11 \\
INJECTION & 0 & 0 & 3 & 5 & 0 \\
OBSERVATION & 0 & 13 & 4 & 0 & 8 \\
UNKNOWN & 0 & 0 & 0 & 58 & 80 \\
\hline TOTAL & 46 & 65 & 52 & 5 & 25 \\
\hline
\end{tabular}

Sources: 1975-1978 estimates are from Geothermal Energy Magazine Annual Drilling Summaries.

1979 estimates are from the Geothermal Progress Monitor Drilling file. These include 9 wells for which spud dates but no completion date or footage were reported by $2 / 15 / 80$. 
Table VII.3

SUMMARY OF GEOTHERMAL DRILLING BY STATES

IN THE WESTERN U.S., 1975-1978*

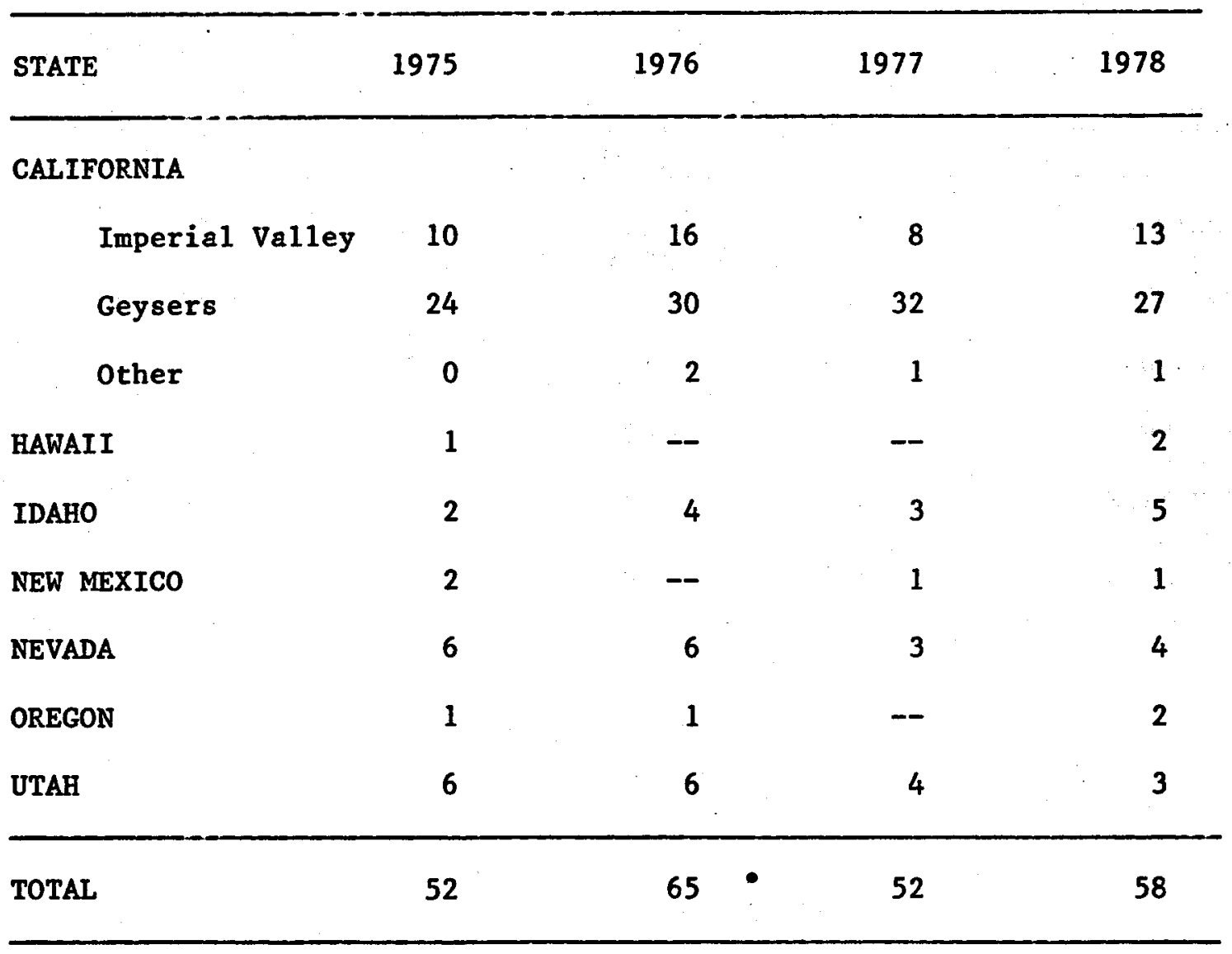

*From Geothermal Energy Magazine Geothermal Drilling Summaries. 